\title{
Agronomic characteristics and shallot production in Tomohon city, North Sulawesi
}

\author{
Olvie G. Tandi*, Herlina N. Salamba, Meivie Lintang, and Bonifasius Mongan
}

Assessment Institute for Agricultural Technology of North Sulawesi Province, Kalasey, Manado, Indonesia

\begin{abstract}
The research aims to study the agronomic characteristics and production of shallots on three different varieties. The study used a Randomized Block Design using 3 varieties, Lansuna, Bima Brebes, and Trisula, with 5 replications. Fertilization based on the recommendations of the Vegetable Research Institute is manure $5 \mathrm{t} \mathrm{ha}^{-1}$, Ponska $600 \mathrm{~kg} \mathrm{ha}^{-1}, \mathrm{KCl}$ $150 \mathrm{t} \mathrm{ha}^{-1}$, and Fertifos $100 \mathrm{~kg} \mathrm{ha}^{-1}$. Fertilization is done 4 times, first when planting, and when the plant is 15,30 , and 45 days after planting. Parameters in the form of plant height, number of leaves, number of seeds, the diameter of tubers, weight of fresh and dried tubers. Data analysis using ANOVA and Duncan's Smallest Real difference test by $5 \%$. The results showed that the height of the plant and the number of leaves of the Bima Brebes variety differed markedly with the varieties Trisula and Lansuna varieties. At the same time, the number of seeds indicates that Trisula differs markedly from Bima Brebes and Lansuna. The diameter of tubers shows Lansuna is significantly different from the Bima Brebes and Trisula. At the same time, the fresh weight and dry weight of Bima Brebes are significantly different from Lansuna and Trisula.
\end{abstract}

\section{Introduction}

Shallots (Allium ascalonicum var. aggregatum) is one of the important vegetables that has high economic value with increasing demand [1]. Soaring shallot prices in 2013 to reach 100,000 -rupiah $\mathrm{kg}^{-1}$ makes this commodity classified as one of the commodities that affect inflation [2]. Minahasa Regency, North Sulawesi Province is one of the developing areas for the production of shallots by those listed in the National Horticultural Masterplan of 2015. In addition to Minahasa regency, Tomohon city also has the potential for the development of shallots in North Sulawesi where it is supported by the location of the area with hilly topography, the height of the place is about 500-700 meters from sea level, cool air, and flanked by two volcanoes namely Mount Lokan and Mahawu, thus making most of the agricultural land in the city of Tomohon is very fertile and suitable for the cultivation of seasonal crops such as shallots [3].

The need for shallots in North Sulawesi both shallots consumption and seeds for propagation is still needed even still imported from Java island such as Brebes and Enrekang, South Sulawesi [4]. The provision of shallot seeds in production centers both in the old

* Corresponding author: olvietandi@gmail.com 
production centers and in potential production centers needs to be developed through the provision of shallot seeds that have adapted in the local environment and are expected to have advantages in environmental adaptation, higher productivity, and resistance to disease in their respective locations compared to onion seeds that have been imported from outside the region for seeds. Local varieties that have high productivity can compete with onion seeds imported from outside the region so that local shallots need seed propagation, seed distribution, and variety registration so that farmers can know the identity of the shallots.

The main limiting factor in shallot farming is the limited availability of quality superior seeds [5]. Quality seeds are seeds with a high level of purity and vigor while seed varieties are superior seeds that have high yield potential, good quality, and production efficiency [6]. North Sulawesi province as one of the centers of shallot production needs quality superior seeds in sufficient quantities to increase production. Quality superior seeds planted in North Sulawesi Province adaptive to the growing environment so that they can produce to the maximum. Agroecosystem conditions in various regions in Indonesia are a challenge to continue producing shallots with high production [7].

Crop productivity, in addition to being determined by growing environmental factors, is also influenced by the ability to adapt varieties to the environment. The use of diverse varieties in the same growing environment will give an idea of the adaptability of the variety in question. The use of less adaptive varieties of shallots will decrease productivity and crop production activities become less effective. One of the technologies that play a role in improving productivity is the use of superior varieties that are by agro-ecological conditions, willingness, and the ability of farmers to develop varieties. Some of the superior varieties of shallots including Pikatan and Mentes are reported to be able to produce $20 \mathrm{t} \mathrm{ha}^{-1}$ in Brebes Regency, Central Java, and become an adoption option by local farmers [8]. Varieties of shallots for dry land are Kramat 1, Kramat 2, and Kuning with a potential yield of $20 \mathrm{tha}^{-1}$ [9].

The research was showed that Mounjung and Semenep varieties in Ambawang river, Kubu Raya Regency of West Kalimantan can adapt well, relatively resistant to Alternaria porii disease, producing dry weights of 11.10 and $12.43 \mathrm{t} \mathrm{ha}^{-1}[10]$. But there are many more varieties of shallots that have higher yield potential, some can even reach $23 \mathrm{tha}^{-1}$ for example Sembrani variety [11]. Each type of agroecosystem has different problems and constraints. Especially in the city of Tomohon, the constraint is that farmers are used to planting leek plants, while not many onions grow it. In addition, the acceptance of farmers to a variety is related to the likes of local farmers such as harvest age, tubers form, resistance to disease pests, and fruit quality.

One of the seed varieties developed in North Sulawesi is the Red Onion Lansuna Variety. The quality of Lansuna production at the farmer level is around 7-8 $\mathrm{t} \mathrm{ha}^{-1}$ meanwhile, the results of the AIAT in North Sulawesi, the production of the Lansuna varieties around $21 \mathrm{t}$ $\mathrm{ha}^{-1}$ [3]. Varieties shallot seeds remains certified. Shallot varieties Lansuna has been released with the Decree of the Minister of Agriculture of the Republic of Indonesia Number 044/Kpts/SR.120/D.2.7/5/2016. The research aims to found the agronomic characteristics and production of shallots on three different varieties. The three varieties are Lansuna, Bima Brebes, and Trisula varieties.

\section{Methodology}

\subsection{Time and location}

The research was conducted from June 2018 to September 2018 in Kamasi subdistrict, central Tomohon Sub district (550 meters above sea level), Tomohon city, North Sulawesi. 


\subsection{Method}

Research using Randomized Block Design, treatment consists of red onion varieties Lansuna, Bima Brebes, and Trisula with 5 replications. Before planting first done seed selection to remove seed tubers that are rotten, defective, and affected by plant pest organism. The technology components used are (1) planting distance $20 \mathrm{~cm} \times 20 \mathrm{~cm}$, (2) using mulch plastic, (3) seeds cut into the ends and inserted into a solution of dithane that contains mancozeb $80 \%$ for 30 minutes after it is immersed into the soil $2 / 3$ part of the tubers. (4) Fertilization based on recommendations namely manure five $\mathrm{t} \mathrm{ha}^{-1}$, Ponska $600 \mathrm{~kg} \mathrm{ha}^{-1}$ and $\mathrm{KCl} 150 \mathrm{t} \mathrm{ha}^{-1}$, Fertifos $100 \mathrm{~kg} \mathrm{ha}^{-1}$. Basic fertilizer in the form of manure $5 \mathrm{t} \mathrm{ha}^{-1}$, and inorganic fertilizer $(1 / 2$ dose $)$ in the form of Ponska, $\mathrm{KCl}$, and fertiphos, and the land is left for 2 weeks. While fertilization follow-up $1 / 2$ dose of the remaining basic fertilizer given at the age of $10-15$ days after planting, follow-up II age 30 days after planting (DAP) and at 45 DAP each 1/3 parts. (5) Pest and disease control in technical, biological, and chemical culture in the concept of Integrated Pest Disease Control (IPM) and environmentally friendly.

\subsection{Data collection and analysis}

Data collections were made on 10 plants on each of the plants aged 15, 35 and 65 days after planting. The observed variables include growth components namely plant height $(\mathrm{cm})$, number of leaves (strands), number of tubers (seed) and diameter of tubers (cm), while the resulting components include weight fresh tubers (gr per clump), dry tubers weight (gr per clump) and total production ( $\mathrm{t} \mathrm{ha}^{-1}$ ). Data processing is done using SPSS software version23 application. The observation data were analyzed with the F test while differences between treatments were tested with Duncan Multiple Range Test (DMRT) at a rate of 5\% [12].

\section{Results and discussion}

\subsection{Plant height}

The results of the analysis variance showed that the location-specific cultivation treatment did not have a noticeable influence on the height of the plant at the observation of 15 days after planting. On observations of 30 days after planting, it was seen that the three varieties of Bima Brebes, Lansuna, and Trisula showed a noticeable difference and the highest height of all varieties tested was the Trisula variety of $34.30 \mathrm{~cm}$, followed by Bima Brebes 26.84 $\mathrm{cm}$ and Lansuna $26.40 \mathrm{~cm}$. Observations during the harvest of 65 days after planting varieties Lansuna showed the highest real difference of 41.34 followed by Trisula $40.54 \mathrm{~cm}$ and the lowest in the variety Bima Brebes of $29.96 \mathrm{~cm}$. The results of [13] stated that morphologically, Lansuna has longer leaves and a larger leaf diameter than Bima Brebes. This indicated that both varieties show different responses. Bima Brebes is a variety for lowland, so it shows relatively slow growth if planted in the middle to high plains.

The appearance of a variety can be influenced by environmental factors $[14,15]$. Some genetic and environmental factors have a close relationship that cannot be separated from each other. If environmental factors are suitable for plant growth, plants will be produced with optimal appearance as well. 
Table 1. Average height of plants at age 15,30, and at 65 DAP on the treatment of three varieties of shallots, at demonstration plot, village Kamasi, Tomohon City.

\begin{tabular}{lccc}
\hline \multirow{2}{*}{$\begin{array}{c}\text { Treatment } \\
\text { (Varieties) }\end{array}$} & \multicolumn{3}{c}{ Plant Height $(\mathbf{c m})$} \\
\cline { 2 - 4 } & 15 DAP & 30 DAP & 65 DAP \\
\hline Bima Brebes & $8: 10^{\mathrm{a}}$ & $26.84^{\mathrm{a}}$ & $29.96^{\mathrm{a}}$ \\
Lansuna & $6: 74^{\mathrm{a}}$ & $26.40^{\mathrm{a}}$ & $41.34^{\mathrm{b}}$ \\
Trisula & $5: 68^{\mathrm{a}}$ & $34.30^{\mathrm{b}}$ & $40.54^{\mathrm{b}}$ \\
\hline
\end{tabular}

a,b in a column followed by followed by the same leter means there is no significant different at the $5 \%$ level using DMRT

Table 2. Average Number of leaves, Number of Tubers and Diameter of tubers aged 65 days after planting on the treatment of three varieties of shallots, the Location demonstration plot Village Kamasi, Distric Central Tomohon, Tomohon City.

\begin{tabular}{lccc}
\hline $\begin{array}{r}\text { Treatment } \\
\text { (Varieties) }\end{array}$ & $\begin{array}{c}\text { Number of Leaves } \\
\text { (strands) }\end{array}$ & $\begin{array}{c}\text { Number of Tubers } \\
\text { (seed) }\end{array}$ & $\begin{array}{c}\text { Diameter of Tubers } \\
\text { (cm) }\end{array}$ \\
\hline Bima Brebes & $20,10^{\mathrm{a}}$ & $7^{\mathrm{a}}$ & $1.96^{\mathrm{a}}$ \\
Lansuna & $25,85^{\mathrm{ab}}$ & $6^{\mathrm{ab}}$ & $2,86^{\mathrm{b}}$ \\
Trisula & $30,89^{\mathrm{b}}$ & $5^{\mathrm{b}}$ & $2,10^{\mathrm{a}}$ \\
\hline
\end{tabular}

$\mathrm{a}, \mathrm{b}$ in a column followed by followed by the same leter means there is no significant different at the 5\% level using DMRT

\subsection{Number of leaves and tubers}

The analysis variances showed that the location-specific cultivation treatment had a noticeable influence on the number of leaves, tubers, and the diameter of the varieties of shallots tested (Table 2). The highest number of leaves in the Trisula variety (30,89 strands) is statistically different from the Lansuna variety (25,85 strands), and Bima has 20,10 strands. While the varieties Lansuna and Trisula there are not significantly different. For the number of tubers, it is statistically noticeable that varieties Bima Brebes and Trisula showed noticeable differences, whereas Lansuna and Trisula did not differ markedly. The highest average number of tubers is in Bima Brebes varieties of 7 seeds, followed by Lansuna 6 seed varieties and the lowest in Trisula varieties as much as 5 seeds (Table 2). The opinion of [16] explains this. The larger the size of the seedlings, the larger the carbohydrates they contain and can provide a lot of food reserves needed for further growth in the field so that the ability to produce shoots will also be larger than small tubers.

For the size of the diameter of tubers statistically, there is a noticeable difference between the Lansuna variety and two other varieties, namely Bima Brebes and Trisula. Whereas the two have no real difference. The highest average diameter of tubers is in the Lansuna variety of $2,86 \mathrm{~cm}$, followed by Trisula $2.10 \mathrm{~cm}$ and the lowest in Bima Brebes variety which is 1,96 $\mathrm{cm}$ (Table 2). According to Asgar and Yusdar [17], the results of fertilization treatment do not affect the diameter of tubers. Therefore, the diameter of the tubers tends to be genetically influenced by plants.

Table 3. The average weight of fresh tubers g per clump, dry tubers weight g per clump, and total production of $\mathrm{t} \mathrm{ha}^{-1}$ in the treatment of three varieties of shallots in the Location demonstration plot Village Kamasi, Distric Central Tomohon, and Tomohon City.

\begin{tabular}{lccc}
\hline $\begin{array}{c}\text { Treatment } \\
\text { Varieties }\end{array}$ & $\begin{array}{c}\text { Weight fresh tubers } \\
\text { (gr per clump) }\end{array}$ & $\begin{array}{c}\text { Dry tubers weight } \\
\text { (gr per clump) }\end{array}$ & $\begin{array}{c}\text { Total Production } \\
\text { (t ha }^{-1} \text { ) }\end{array}$ \\
\hline Bima Brebes & $36,17^{\mathrm{a}}$ & $30,92^{\mathrm{a}}$ & $9,04^{\mathrm{a}}$ \\
Lansuna & $56,08^{\mathrm{b}}$ & $42,18^{\mathrm{b}}$ & $16,02^{\mathrm{b}}$ \\
Trisula & $47,26^{\mathrm{b}}$ & $37,30^{\mathrm{b}}$ & $11,81^{\mathrm{ab}}$ \\
\hline
\end{tabular}

$\mathrm{a}, \mathrm{b}$ in a column followed by followed by the same leter means there is no significant different at the $5 \%$ level using DMRT 


\subsection{Fresh and dry weight of tubers and production}

The results of the analysis variance showed that site-specific cultivation treatment had a noticeable influence on the weight of fresh tubers, the weight of $g$ plant ${ }^{-1}$ dry tubers, and the production of the varieties of shallots tested (Table 3 ). The average weight of fresh tubers shows a noticeable difference. The highest at varieties Lansuna is $56.08 \mathrm{~g} \mathrm{plant}^{-1}$, followed by Trisula varieties 47.26 and the lowest varieties Bima Brebes $36.17 \mathrm{~g} \mathrm{plant}^{-1}$. While the varieties Lansuna and Trisula are no real difference. For the average variable weight of dry tubers (Table 3), there is a noticeable difference between Lansuna varieties against two other varieties, namely Brebes and Trisula, where the highest value of dry weight Lansuna varieties is $42.18 \mathrm{~g} \mathrm{clump}^{-1}$, followed by Trisula $37.30 \mathrm{~g} \mathrm{clump}^{-1}$ and the lowest in the variety Bima Brebes of $30.92 \mathrm{~g} \mathrm{clump}^{-1}$. While the average production of the three varieties tested showed a noticeable difference, the highest production average was in the Lansuna variety of 16.02 $\mathrm{t} \mathrm{ha}^{-1}$, followed by the Trisula variety of $11.81 \mathrm{tha}^{-1}$ and the lowest in the treatment of Bima Brebes varieties of $9.04 \mathrm{tha}^{-1}$.

The success of growth until the production of shallots, the other is influenced by the potential and quality of seeds or seeds sourced from various types of varieties, also highly dependent on the potential of the environment as a place of cultivation, including the height of the place, the state of the climate and the fertility rate of the soil. According to Suryana [18], plants grow and thrive when the nutrients given can be absorbed by a plant and in the form needed for its growth. Enough nutrients for onions can increase the weight of the bulbs of the crop [19]. Potassium is indispensable for the process of photosynthesis process and can increase the weight of shallot tubers [20]. Furthermore, Fatmawaty et al. [21] the provision of NPK compound fertilizer can affect the increase in shallots' growth and yield and increase crop yields. According to Asrijal et al. [22], the growth and production of shallots are influenced by the potential and quality of seeds or seeds sourced from various types of varieties.

\section{Conclusions}

The results showed that the three superior varieties of shallots tested showed a good growth appearance and results. The average yield achieved is around $12.29 \mathrm{t} \mathrm{ha}^{-1}$. Lansuna variety produced the highest production of $16.02 \mathrm{t} \mathrm{ha}^{-1}, 11.81 \mathrm{t} \mathrm{ha}^{-1}$ for Trisula variety, and Bima Brebes variety of $9.04 \mathrm{t} \mathrm{ha}^{-1}$. These three varieties can be recommended to be developed in Tomohon, North Sulawesi, as other farming alternatives.

\section{References}

1. Nurviani, S. Sulandari, S. Somowiyarjo, S. Subandiyah, Jurnal Fitopatologi Indonesia 12, 5 (2016)

2. M.A. Firmansyah, D. Musaddad, T. Liana, M. Mokhtar, M. Yufdi, J. Hortik. 24, 2 (2014)

3. BPS Kota Tomohon, Tomohon Dalam Angka (Timohon, 2020)

4. Laporan Kemitraan BPTP Sulut, Laporan Akhir Kegiatan Kemitraan Budidaya Bawang Merah di Kota Tomohon Provinsi Sulawesi Utara (Badan Litbang Pertanian, Kementerian Pertanian, 2018)

5. E. Iriani, J. Litbang Provinsi Jawa Tengah 11, 2 (2013)

6. Z. Zaini, J. Pengemb. Inov. Pertan. 2, 1 (2009)

7. F. Yuliani, Respon morfologi dan fisiologi tanaman bawang merah (Allium cepa L.) terhadap cekaman salinitas (Tesis, Institut Pertanian Bogor, 2017) 
8. I.M. Hidayat, S. Putrasameja, dan C. Azmi. 2011. Persiapan pelepasan varietas bawang merah umbi dan TSS (Laporan Kegiatan Tahun 2011, Balai Penelitian Tanaman Sayuran, Lembang, 2011)

9. N. Sumarni, A. Hidayat, Panduan teknis PTT bawang merah (Balai Penelitian Tanaman Sayuran, Bandung, 2005)

10. T. Purbiati, A. Umar, A. Supriyanto, Laporan Pengkajian Adaptasi Varietas Bawang Merah Toleran Hama Penyakit Pada Lahan Kering di Kalimantan Barat (BPTP Kalimantan Barat, 2010)

11. Puslitbang Hortikultura, Bawang Merah Sembrani Berani dan Tahan Uji di Lahan Gambut (Badan Litbang Pertanian, 2014)

12. K.A. Gomez, and A.A. Gomez. Statistical procedures for agricultural research $\left(2^{\text {nd }}\right.$ ed. John Wiley \& Sons, New York, 1984)

13. F.I. Nuryana, H. Harti, A. Maharijaya, Horticulture J. 2, 1 (2018)

14. B. Abdullah, Pengenalan Karakter Penciri Varietas. Makalah Lokakarya Pengembangan Jaringan Alih Teknologi Produksi dan Distribusi Benih Sumber (Balai Penelitian Tanaman Padi, 2005)

15. A.S. Bari, Muda, E. Syamsudin, Pengantar Pemuliaan Tanaman. Departemen Agronomi (Fakultas Pertanian, Institut Pertanian Bogor, 1974)

16. Suwandi, Y. Hilman, Budidaya Tanaman Bawang Merah, Teknologi Produksi Bawang Merah, Pusat Penelitian dan Pengembangan Hortikultura (Badan Penelitian dan Pengembangan Pertanian, 1995)

17. A. Asgar, H. Yusdar, Buletin Penelitian Hortikultura 27, 4 (1995)

18. N.K. Suryana, J. Agrisains. 9, 2 (2008)

19. D. Napitupulu, I. Winarto, Jurnal Hortikultura 20, 1 (2010)

20. M.M.B. Damanik, B. E. Hasibuan, Fauzi, Sarifuddin, H. Hanum, Kesuburan Tanah dan Pemupukan (Universitas Sumatera Utara, Medan, 2010)

21. A.A. Fatmawaty, S. Ritawati, L.N. Said, Jurnal Agrologia 4, 2 (2015).

22. Asrijal, E. Syam'un, Y. Musa, M. Riadi, Int. J. Curr. Microbiol. App. Sci. (IJCMAS) 7, $5(2018)$ 